\title{
An Epilogue To Bilateral Investment Treaties Regime And The Fate Of Foreign Investments Protection In Indonesia
}

\author{
Nur Gemilang Mahardhika \\ Fakultas Hukum Universitas Islam Indonesia Yogyakarta Indonesia \\ Jln. Tamansiswa No. 158 Yogyakarta Indonesia \\ gemilang.mahardhika@uii.ac.id
}

Received: 13 Agustus 2021; Accepted: 28 Januari 2022; Published: 31 Januari 2022

DOI: 10.20885/iustum.vol29.iss1.art5

\begin{abstract}
Indonesia began its BITs termination movement in early 2014 by calling off the Netherlands-Indonesia BIT 1992. As of today, 29/55 of the country's BITs that are in force have been terminated. By adopting the normative research method and utilising statutory and conceptual approaches, this paper examines two issues: first, mapping the landscape of international investment law in Indonesia in the epilogue of its long-standing BITs regime hence the probable government's deliberations behind the action; and second, in what way would the BITs termination movement truly serve Indonesia's national interests and benefit its economic development while promoting and protecting foreign investments - particularly on the core element of the investors' direct right to investment arbitration. At last, the paper concludes its discussion by offering two answers: first, two lifeboats are reserved for the protection of the country's present foreign investment, the implementation of "Sunset Cause" contained within Indonesia's BITs as well as protectionism provisions under the country's national investment law and other relevant regulations; and for the second, two diverged roads are laid out to choose for the protection of future foreign investments in Indonesia, the country's Regional Trade Agreements (RTAs) containing investment provisions or its newly born model BIT which, needless to say, at least the latter must be formulated with delicate manner if the goal is to prevail Indonesia's interests.
\end{abstract}

Key Words: Bilateral Investment Treaties; foreign investors; investor-state contracts; new model BIT; Regional Trade Agreements; sunset clause

\section{Abstrak}

Indonesia memulai gerakan terminasi BIT-nya sejak awal tahun 2014 dengan membatalkan BIT BelandaIndonesia 1992. Sampai hari ini, dari total 55 BIT negara tersebut yang masih berlaku, 29 di antaranya telah dihentikan. Dengan mengadopsi metode penelitian normatif dan menggunakan pendekatan perundangundangan dan konseptual, tulisan ini mengkaji dua masalah: pertama, pemetaan lanskap hukum investasi internasional di Indonesia dengan berakhirnya rezim BIT yang sudah berlangsung lama juga analisa kemungkinan pertimbangan-pertimbangan pemerintah di balik tindakan tersebut; dan kedua, dengan cara apa gerakan terminasi BIT ini dapat benar-benar melayani kepentingan nasional Indonesia dan menguntungkan pembangunan ekonominya namun pada saat yang bersamaan juga mempromosikan dan melindungi investasi asing - terutama pada elemen inti yakti hak langsung investor untuk mengajukan arbitrase. Sebagai penutup, makalah ini mengakhiri diskusinya dengan menawarkan dua jawaban: pertama, dua sekoci disediakan untuk melindungi investasi asing negara saat ini, yaitu penerapan "Sunset Cause" yang terkandung dalam BIT Indonesia serta pasal-pasal pelindung dalam UU Investasi negara tersebut serta peraturan terkait lainnya; dan untuk yang kedua, dua pilihan jalan ditawarkan untuk melindungi investasi asing di Indonesia di masa depan, yaitu Regional Trade Agreement (RTA) negara tersebut yang mengandung bab investasi atau model BIT baru yang akan lahir yang, tentunya, paling tidak yang terakhir ini harus dirumuskan secara hati-hati jika tujuannya adalah untuk memenangkan kepentingan Indonesia.

Kata-kata Kunci: Bilateral Investment Treaty; investor asing; perjanjian investor-negara; model BIT baru; Regional Trade Agreement; Sunset Clause 


\section{Introduction}

Just like many other branches of international law, international investment law started off as customary international law (CIL) before it is governed by a vast global network of Bilateral Investment Treaties (BITs). Some of the highlighted features of international investment law during its CIL era that are later adopted into its BITs regime are minimum standards of treatment and along with it, the national treatment principle. However, there are at least three characteristics that situate international investment in CIL under stark contrast to its treaty regime: first, as the product of enduring state practise and opinio juris, ${ }^{1}$ the rules of international investment under CIL bind all states in the world, regardless the absence of apparent codification; second, on the ground of sovereign equality, ${ }^{2}$ they tend to demonstrate a set of general state-centric rules rather than the specific investor-centric ones; third, despite the slow process of their creation, they are still deemed to be evolutionary, changeable and can very much develop across time, which gives them the winning point against the stagnancy of treaties.

Nonetheless, the emergence of BITs somehow demonstrates that the CIL era had not been favourable especially for the investors, for instance, the 1930 Mexico Nationalisation of oil and gas sector. The probable reasons being, for one, foreign investors supposedly enjoy protection of themselves and their assets by the host state ${ }^{3}$ yet there was no direct right of the investors to bring claims against the host government before any tribunals when dispute arises except in their homeland. ${ }^{4}$ There is also Root's view on national treatment that uses the benchmark of "established standard of civilisation" 5 which was challenged by the Calvo Doctrine

\footnotetext{
${ }^{1}$ The believe and acceptance of the international society for general practice to be recognized as part of customary law, in Christian Dahlman, "The Function of Opinio Juris in Customary International Law", Nordic Journal of International Law, Vol. 81, Issue 3, 2012, p. 327

2 The term was first proclaimed in the 1943 Declaration of Moscow by the United States, United Kingdom, Soviet Union and China. In short, it is defined as "no state can be legally bound under international law against its will" and it is only international law that can bind state, not the national law of other state, in Hans Kelsen, "The Principle of Sovereign Equality of States as A Basis of International Organisation", Yale Law Journal, Vol. 53, 1944, p. 209

3 It was during the period of late $19^{\text {th }}$ to the early $20^{\text {th }}$ century that legal status and economic interests of foreign nationals started to be recognised as part of diplomatic protection due to the increasing international trade and foreign investments activities, in Elihu Root, "The Basis of Protection to Citizen's Residing Abroad", American Journal of International Law, Vol. 4, Issue 3, 1910, p. 518-519

4 Andrew Newcombe and Lluis Paradell, Law and Practise of Investment Treaties, Kluwer, 2009, p. 5-6

5 The "civilised" nature refers to what has been fashioned by the developed nations for the developing ones: if the latter treats their citizens poorly and below the established minimum standard, then the minimum standard prevails, in Elihu Root, "The Basis...Op. Cit., hlm. 521-522
} 
which views otherwise on the ground of non-intervention. ${ }^{6}$ Another point of conflict, somewhere along the line, the scope of protection was increased from mere individual justice against the abuse of power by host states to protection of properties by applying the Hull Rule with such high bar of prompt, effective and adequate compensation, ${ }^{7}$ which in 1960 's, it was declined to mere "appropriate compensation" by the developing nations-led UNGA Resolution 1803. ${ }^{8}$

World's first ever BIT was signed in 1959 between West Germany and Pakistan, ${ }^{9}$ supposedly a template treaty with open-ended language to achieve uniformity that has cemented the first building brick to the establishment of the regime: thrusting the free-falling minimum standard of treatment back up by reestablishing prompt and adequate compensation in the amount equivalent to the investment made, ${ }^{10}$ thus the beginning of a more investor-centric regime. From that moment on, repeat players of the dominant European nations resume their role as the international law-makers by entering into BITs, ${ }^{11}$ while the other nations follow the global economic drift that they have created. ${ }^{12}$ Believed to be the fitting legal instrument to attract the flow of foreign capital ${ }^{13}$ therefore spreading invitations to establish foreign direct investment (FDI) in their territory; ${ }^{14}$ as well as sending out signals of their government's "credible commitment" on the protection of foreign investments have also been some of the motivations as to why states, especially those of the developing economies, are

\footnotetext{
${ }^{6}$ DR Shea, The Calvo Clause, University of Minnesota Press, Minnesota, 1955, p. 18

7 United States Secretary of State, "Mexico-United States: Expropriation by Mexico of Agrarian Properties Owned by American Citizens”, American Journal of International Law, Vol. 33, 1983, p. 191-201

8 Permanent Sovereignty Over Natural Resources, GA Res. 1803 (XVII), UN GAOR, 28 ${ }^{\text {th }}$ sess, Supp No 17, UN Doc. A/5217 (14 December 1962)

${ }^{9}$ Treaty for the Promotion and Protection of Investments (with Protocol and Exchange of Notes), Germany-Pakistan, signed 25 November 1959, 457 UNTS 24 (entered into force 28 November 1962) ['Germany-Pakistan BIT']

${ }^{10}$ Ibid Art.3

11 Zachary Elkins, Andrew T Guzman and Beth A. Simmons, "Competing for Capital: The Diffusion of Bilateral Investment Treaties, 1960-2000”, International Organization, Vol. 60, No. 4, 2006, p. 816

12 Andrew Guzman, "Why LDCs Sign Treaties that Hurt Them; Explaining the Popularity of Bilateral Investment Treaties", Virginia Journal of International Law, Vol. 38, 2006, p. 639

13 Siemes $A G v$ The Argentine Republic (Jurisdiction) (ICSID Arbitral Tribunal) Case No. ARB/02/8 (3 Agustus 2004) [81]

14 Prabash Ranjan, "Indian Investment Treaty Program in Light of Global Experience", Economic and Political Weekly, Vol. 39, No. 45, 2010, p. 68
} 
willing to enter into more and more BITs that it eventually creates a vast network of law, ${ }^{15}$ without knowing what might hit them.

Presently there are over 3,000 BITs in the world with the classic grouping of developed-developing countries (known as the North-South treaties - although the South-South or even North-North ones are known to exist). As a global network, BITs all over the world typically consist of nine similar provisions: definition of investment and the scope of application; investment promotion and conditions of entry; standard of treatment; monetary transfer; expropriation and nationalisation; general operational and management of assets; protection and compensation for internal disorder; exceptions, modifications and termination of the BIT; and most importantly, dispute settlement mechanism, ${ }^{16}$ which in this case, ICSID and the likes were born to provide both legal and institutional framework for investment disputes, ${ }^{17}$ by introducing the feature of investor-state arbitration tribunal as the heart of the delocalised BITs regime.

Nevertheless, BITs are not destined to last forever but, in the age where international investment law is still widely governed under the treaty regime, they are expected to last a little bit longer. However, since late 2012, a good number of states, particularly the developing capital-importer ones, have cancelled, withdrawn from or terminated their BITs. ${ }^{18}$ Making it seem as if it is a current sporadic global trend opposite to what have been established before. Such move is unexceptionally followed by one particular nation, a little fish in a mighty ocean of international investments: Indonesia. The country began by terminating

\footnotetext{
${ }^{15}$ Lauge Poulsen, "Bounded Rationality and the Diffusion of Modern Investment Treaties", International Studies Quarterly, Vol. 58, Issue 1, 2014, p. 1-3

${ }^{16}$ Jeswald W Salacuse, "The Emerging Global Regime for Investment", Harvard International Law Journal, Vol. 51, No. 2, 2010, p. 432

${ }_{17}$ Convention on the Settlement of Investment Disputes Between States and Nationals of Other States, opened for signature 18 March 1965, 575 UNTS 159 (entered into force 14 October 1966)

${ }^{18}$ Norton Rose Fulbright, "Indonesia Signals Intention to Terminate More than 60 Bilateral Investment Treaties", Norton Rose Fulbright in http://www.nortonrosefulbright.com/knowledge/ publications /116101/indonesia-signals-intention-to-terminate-more-than-60-bilateral-investment-treaties, accessed in 5 November 2018
} 
its BIT with the Netherlands in early $2014 .{ }^{19}$ In the present day, out of 55 of its BITs that are in force, 29 of it has been terminated. ${ }^{20}$

There are undoubtedly multiple considerations as to why Indonesia decided to go down that road. But to draw one prefatory answer from the pool of possibilities, the move might have been highly influenced by the outcome of the Churchill Mining and Planet Mining arbitration tribunals. ${ }^{21}$ The International Centre for Settlement of Investment Disputes (ICSID) had delivered the awards that favoured Indonesia. But as reflected in the decisions, it was done so on the ground of mere obscurity in both applicable BITs between Indonesia and Australia, as well as that of Indonesia and the United Kingdom, on the specific clause of choice of forum. On a justifiable ground of presumption, the Indonesian government might have taken that as a call to review and renegotiate its current existing BITs, as allegedly, termination of BITs is the means to reach to that desired end. Yet, in the absence of BITs, foreign investors may no longer enjoy their one significant right, the key feature of investments protection under the investment treaty regime, that is to bring claim against the host-state government before an investor-state dispute settlement (ISDS) forum shall investment dispute arise between them.

In the light of that, the paper highlights two issues: what would happen to the present foreign investments in Indonesia in the epilogue of the country's BITs regime and why did the government do so; as well as how to ensure that the BITs termination movement would truly serve the country's national interests and nurture its economic development while at the same time, progressing with its liberalisation commitment to promote and protect foreign investment.

\section{Problems Formulation}

This paper discusses these following problems: 1) How is the landscape of Indonesia's international investment law in the epilogue of its BITs regime and

${ }^{19}$ Leon E Trakman and Kunal Sharma, "Why is Indonesia Terminating Its Bilateral Investment Treaties?", Kluwer Arbitration, in http://arbitrationblog.kluwerarbitration.com/2014/08/21/indonesias-termination-of-thenetherlands-indonesia-bit-broader-implications-in-the-asia-pacific/, accessed in 29 December 2021

${ }^{20}$ United Nations Conference on Trade and Development (UNCTAD), "Indonesia Bilateral Investment Treaties", Investment Policy Hub, in http://investmentpolicyhub.unctad.org/IIA/CountryBits/97, accessed in 5 November 2018

21 Churchill Mining PLC and Planet Mining Pty Ltd $v$ Republic of Indonesia (Jurisdiction) (ICSID Arbitral Tribunal) Cases No. ARB/12/14 and ARB/12/40 (24 February 2014) 
what are the probable government's deliberations behind the action? 2) How would the BITs termination movement truly benefit Indonesia's economic development while promoting and protecting foreign investments, particularly on the issue of the investors' direct right to ISDS?

\section{Research Objectives}

This paper is hoped to contribute a literacy to view the new landscape of international investment law in Indonesia after the closure of the country's BITs regime by addressing the abovementioned problems with analysis on the foreign investment protection under the "Sunset Clause" left by a number of BITs as well as protection under Indonesian national investment law and other relevant regulations. Additionally, the paper is designed to measure two diverged roads to choose for further commitment of foreign investment protection in Indonesia: Regional Trade Agreements (RTAs) with investment provisions under which Indonesia is a party; or the newly born model of Indonesia's BIT.

\section{Methodology}

This research paper is of normative nature which was born of a complex study with both statutory and conceptual approaches. It was done so by utilising the primary legal materials that comprise of both international law sources such as international (investment) agreements as well as relevant Indonesian national laws; as for the secondary legal materials, library study was conducted on a good number of books, journal articles, reports, documents, other researches of similar nature and other articles. Everything is eventually deduced in qualitative analysis and presented in a descriptive manner.

\section{Results and Discussions}

The Landscape of Indonesia's International Investment Law in the Epilogue of BITs

To give a little taste of Indonesia's BITs, this paper provides brief examinations the 1994 BIT with the Netherlands 22 that has replaced the 1968 one $^{23}$

22 Agreement Between the Government of the Kingdom of the Netherlands and the Government of the Republic of Indonesia on Promotion and Protection of Investments, Netherlands-Indonesia, signed 4 June 1994, 2240 UNTS 323 (entered into force 1 July 1995) ('Netherlands-Indonesia BIT 1994') 
and has been the first to begin the country's massive termination move; BITs with Australia $^{24}$ and the United Kingdom ${ }^{25}$ which the Churchill Mining and Planet Mining decisions were based on; and BITs with Malaysia ${ }^{26}$ and Thailand. ${ }^{27}$ The outcome of Churchill Mining and Planet Mining decisions may or may not render their contribution, but amongst these five BITs, only those of with Australia and United Kingdom (alongside that of with Thailand) remain in force. ${ }^{28}$ The ones with the Netherlands and Malaysia have been unilaterally denounced. ${ }^{29}$

On the first glance, these BITs have demonstrated that Indonesia's fashion of BITs seems to have been a series of frank copied and pasted documents. Indonesia's BITs typically composed of around ten to fifteen pages with the maximum of fifteen articles that govern the similar rules as found in the global BITs network. ${ }^{30}$ Broadness and inclusivity are the two apparent traits of Indonesia's BITs. As the product of globally uniformed law-making, they are intended to grant as much protection as possible to the investors.

Some striking similarities amongst those BITs further confirms the intentional ambiguity of the investment treaty regime. First is the definition of investment, all stand in solidarity by defining "investment" in a very open-ended way with the wordings of "including/in particular, but not exclusively". ${ }^{31}$ Another point of similarity, all provide the same dispute settlement mechanism

23 Agreement on Economic Cooperation, The Netherlands-Indonesia, signed 7 July 1968, 1155 UNTS 243 (entered into force 17 July 1971)

24 Agreement Between the Government of Australia and the Government of the Republic of Indonesia Concerning the Promotion and Protection of Investments, Australia-Indonesia, signed 17 November 1992, 1770 UNTS 301 (entered into force 29 July 1993) ('Australia-Indonesia BIT 1992')

25 Agreement Between the Government of the United Kingdom of Great Britain and Northern Ireland and the Government of the Republic of Indonesia for the Promotion and Protection of Investments, United Kingdom-Indonesia, signed 27 April 1976, 575 UNTS 159 (entered into force 24 March 1977) ('UK-Indonesia BIT 1976')

26 Agreement Between the Government of Malaysia and the Government of the Republic of Indonesia for the Promotion and Protection of Investments, Malaysia-Indonesia, signed 22 January 1994, (entered into force 2 October 1999) ('Malaysia-Indonesia BIT 1994')

27 Agreement Between the Government of the Republic of Indonesia and the Government of the Kingdom of Thailand for the Promotion and Protection of Investments, Indonesia-Thailand, signed 17 February 1998, 1489 UNTS 3 (entered into force 5 November 1998) ('Indonesia-Thailand BIT 1998')

28 United Nations Conference on Trade and Development (UNCTAD), above n 12

${ }^{29}$ See United Nations Conference on Trade and Development (UNCTAD), "Indonesia-Netherlands BIT 1994", Investment Policy Hub, in http://investmentpolicyhub.unctad.org/IIA/mostRecent/treaty/1988, accessed in 5 November 2018

30 Kevin Muhammad Haikal, "Foreign Investment Protection Post-Indonesia's Bilateral Investment Treaties Regime", Thesis, Tilburg University, 2017, p. 29-30

${ }^{31}$ For instance, see Netherlands-Indonesia BIT 1994 art 1 (1) 
by starting with consultations or negotiations but only "if possible". ${ }^{32}$ Otherwise the investors can directly file the claim without the consent of the host government wherein ICSID or United Nations Commission on International Trade Law (UNCITRAL) are the all-time favourites, ${ }^{33}$ although the time frame from the amicable dispute settlement to the investment arbitration may vary amongst BITs. An interesting point is found in both Churchill Mining and Planet Mining BITs, they do not explicitly state time limitation for settling the dispute amicably before pursuing an investment arbitration. ${ }^{34}$

The Netherlands-Indonesia BIT 1994 on the other hand, is the only BIT that limit the investor-state dispute to be "any legal dispute" while the rests are settled with the openness of "any dispute". ${ }^{35}$ While Australia-Indonesia BIT 1992 had been the only one that addresses the issue of investors being the subsidiary of a nonparty third state, although not as much. The Treaty regulates mandatory prior consultation to decide the extended rights of the third state. ${ }^{36}$ Oddly enough, the Netherlands-Indonesia BIT 1994 and the Malaysia-Indonesia BIT 1994 are only the two out of those five BITs that do not contain provision on bestowing protection to the pre-existing investments. ${ }^{37}$

\section{Indonesia's Termination of BITs}

The BITs termination or non-renewal trend has happened since 2012 by developing countries such as India, South Africa, Ecuador, Brazil, Bolivia, Venezuela, even including the first BIT initiator, Pakistan. ${ }^{38}$ Couple years afterwards, Indonesia indifferently followed suit, as stated by the Embassy of the Netherlands in Jakarta that the Netherlands-Indonesia BIT 1994 would finalise its term on the $1^{\text {st }}$ of July 2015 while the Indonesian Government would not open the negotiation for renewal of the BIT. ${ }^{39}$ The termination of Netherlands-Indonesia BIT

\footnotetext{
32 Ibid Art 9 (1)

${ }^{33}$ Ibid Art 9 (2)

34 Australia-Indonesia BIT 1992 Art XI (2) and UK-Indonesia BIT 1976 Art 7 (1)

35 Netherlands-Indonesia BIT 1994 Art 1 (1)

36 Australia-Indonesia BIT 1992 Art III (3)

${ }^{37}$ For instance, see Indonesia-Thailand BIT 1998 Art II (2)

${ }^{38}$ Leon E Trakman and Kunal Sharma, "Why is Indonesia...Loc.Cit.

${ }^{39}$ Kingdom of the Netherlands, “Termination Bilateral Investment Treaty", Embassy of the Netherlands, in http://indonesia.nlembassy.org/organization/departments/economic-affairs/termination- bilateralinvestment-treaty.html, accessed in 5 November 2018
} 
1994 in 2015 has somewhat become the milestone for Indonesia let go of more BITs in the next couple years. There are 72 of Indonesia's BITs in total: 17 of them have only been signed and yet to enter into force, including that of the most recent one with Singapore signed in late 2018 as the replacement for the 2005 one; 29 of them have been terminated; that leaves Indonesia with only 26 BITs to carry on which, it seems as if the clock is ticking for them.

A handful suppositions as to why the Indonesia goes down this road can be drawn from several circumstances which as expected, are more political than economical: the first supposition takes us back to revisit the 1997-1998 Asian financial crisis that destabilises Indonesia's economics and political affairs. As the rupiah collapsed, IMF came to the rescue by offering a $\$ 23$ billion USD support package..$^{40}$ But the debt costs Indonesia to shrink its subsidy for local companies, offer higher liberalisation commitment, and sign up to more BITs. ${ }^{41}$ That being said, Indonesia's BITs are not the products of the country's genuine intent, moreover if the BITs are only "take it or leave it" template agreements. Any affairs one engages in when one is in high level pressures would not serve bona fide return, hence it is natural for the nation to wanting to review its past decisions eventually.

The second consideration is suffered by the developing economies as a whole. BITs simply failed to establish the equilibrium point between foreign investors protection and national interests. Returning to the notion of economic nationalism, ${ }^{42}$ developing countries involve themselves in this rough playground only by the stern yet naïve belief that doing so would satisfy their economic interest. On the contrary, entering into BITs means states lower themselves to be the subject of private law. To some extent, states would have cut off a chunk of their sovereignty. In order to fulfil their treaty obligations, the states' hands are tied from formulating domestic regulations that would uphold their national interests. Indeed, the historical background of BITs during CIL era has drawn a

\footnotetext{
40 Mark Beeson and Andrew Rosser, "The East Asian Economic Crisis: A Brief Overview of the Facts, the Issues and the Future” Working Paper No 86, Asia Research Centre, June 1998, p. 1-2

41 Government of Indonesia, "Letter of Intent", International Monetary Fund, in https://www.imf.org/external/np/loi/1113a98.htm, accessed in 29 December 2021

${ }^{42}$ James H Mathis, "Regional Trade Agreements in the GATT/WTO: Article XXIV and the Internal Trade Requirement”, TMC Asser Press, 2002
} 
picture of states being the sovereign which by nature possess power and control over everything and everyone within its jurisdiction, thus situating foreign investors as the weaker party in need of protection. But in practise, BITs gives more to the investors. BITs in its application impeaches the underlying perception of obligation law: mutual consent and reciprocity of an agreement. ${ }^{43}$ But of course, one may still argue that state sovereignty is not absolute as other international obligations have drawn the boundaries. ${ }^{4}$

Third, the ambiguity of the provisions in BITs. It is established that the coverage of BITs provisions is meant to be as broad as possible, to provide as much protection as possible. But it only leads to the fact that those provisions are simply too broad, that the notion of protection is easily applicable to any sorts of things. As if the inclusive definition of investments in BITs is not enough of a concern, the term "property of foreign investors" is also intentionally inclusive. The words "any asset" have bound states to protect as many assets as the foreign investors' cleverness can come out with: from their actual operational equipment, their office buildings, to their personal vehicles and residences.

Fourth, the legitimacy of BITs. The law-making process in BITs regime is based on its vast global network, but the legitimacy of such system is under constant debate. Not only BITs have become a series of copied and pasted documents drafted by the dominant players and lacking the accord of the developing nations; decision making in BITs regime is intensely privatised and decentralise - it is the non-state actors who elaborate and apply the rules of the regime.45 In comparison with its sister regime, decision making in the international trade law under the WTO is vested on the member states. ${ }^{46}$ In the investment treaty regime, it is vested on the arbitrators. Although they possess no authority to actually make the rules, nor that there is a formal precedent system recognised in the regime, the decisions are repeatedly cited hence gravely

${ }^{43}$ Rudolf Dolzer and Christophe Schreuer, Principles of International Investment Law, Oxford University Press, Oxford, 2012

${ }_{44}$ ADC Affiliate Ltd and ADC \& ADMC Management Ltd $v$ Republic of Hungary (Award) (ICSID Arbitral Tribunal) Case No ARB/03/16 (2 October 2006)

${ }^{45}$ Jeswald W Salacuse, "The Emerging...Op.Cit., p. 466-467

${ }^{46}$ Marrakesh Agreement Establishing the World Trade Organization, opened for signature 15 April 1994, 1867 UNTS 3 (entered into force 1 January 1995) annex 2 ('Understanding on Rules and Procedures Governing the Settlement of Disputes') art 6, 16-17 
influencing the future decision - which obviously not every developing stakeholder is pleased with those decisions. ${ }^{47}$

The legitimacy issue leads to the fifth reason, which is Indonesia's exposure to abundant ISDS forums that not only costed Indonesia billions of dollars, but the outcome of it interferes with its sovereignty. Presently, Indonesia sits on the first rank of ASEAN country with the most investment arbitration cases. ${ }^{48}$ Newmont $v$ Indonesia ${ }^{49}$ although it was later withdrawn, becomes a popular beside Churchill Mining and Planet Mining. The dispute settlement mechanism under BITs grants direct right to the investors to pursue investment arbitration. Additionally, decision of such tribunal, regardless of how disadvantageous it is, would easily disregard the decision of Indonesia's domestic courts. Prior to the termination movement, former President Yudhoyono stated that this country will never again allow multinational corporations carry on with their unequal bargaining power to put pressure on Indonesia. ${ }^{50}$ It is very important to note, however, that the country is not against the reasonable protection of the investors, but rather the "plundering of the foreign companies". 51

However, BITs termination movement is not permanent. Indonesia acknowledges the bedrock for the termination is the existing BITs which are no longer appropriate nor fitting to Indonesia's development progress. ${ }^{52}$ Hence, Indonesia is to renegotiate for the establishment of a new and better BITs regime. 53

\footnotetext{
47 Christhophe Schreuer and Matthew Weiniger, “A Doctrine of Precedent?”, in Peter Muchlinski et al (eds), The Oxford Handbook of International Investment Law, Law-book, 2008, p. 1189

48 S Stephen L. Magiera, "International Investment Agreements and Investor-State Disputes", Discussion Paper No 30, ERIA, January 2017, p. 18

49 Nusa Tenggara Partnership BV and PT Newmont Nusa Tenggara v Republic of Indonesia (Discontinued) (ICSID Arbitral Tribunal) Case No ARB/14/15 (August 2014)

50 Bagus BT Saragih, "SBY Frets Over International Arbitration", The Jakarta Post, in http://www.thejakartapost.com/news/2012/06/29/sby-frets-over-int-l-arbitration.html, _accessed in 29 December 2021

51 John Lumbantobing, "Renegotiating the Bite of Our BITs", Jakarta Post, in http://www.thejakartapost.com/news/2015/05/18/renegotiating-bite-our-bits.html, accessed in 29 December 2021

${ }^{52}$ Kevin Muhammad Haikal, "Foreign Investment...Op.Cit., p. 42, 33

${ }^{53}$ Minister for Foregin Affairs Republic of Indonesia, "Annual Press Statement (2015)", The Ministry of Foreign Affairs Republic of Indonesia, in https://www.kemlu.go.id/Documents/PPTM\%202015/PPTM\%202015\%20ENG\%20FINAL\%20PDF.pdf, accessed in 5 November 2018
} 


\section{The Present: Sunset Clause and Indonesian National Investment Law}

Sunset clause is essentially the lifeboat of any BITs, as the termination provision in BITs has made it possible for one of the contracting parties to terminate their BIT through a simple procedure: the party who intends to terminate the treaty is obliged to write the notification; no explicit obligation for the other party to respond. ${ }^{54}$ This concept inevitably creates the unilateral mode of denouncement. Therefore, sunset clause is fashioned as a precautionary response towards the unilateral termination: the rights of the current investors will not cease to exist at once. For instance, in the Netherlands-Indonesia BIT 1994, the duration of the Treaty is ten years after the ratification by both contracting parties, it is to be continued for another ten years on and on until one send written termination notification to the other one year before the expiration date. ${ }^{55}$ Sunset clause of the Treaty governs the continued protection for the period of fifteen years, but only for the investments made prior to the termination. ${ }^{56}$ In its second decade of being in force, the Netherlands-Indonesia BIT 1994 was scheduled to expire by the $1^{\text {st }}$ of July 2015, the Indonesia delivered its termination note on the $23^{\text {rd }}$ of March 2014. The Dutch investments made in Indonesia prior to 2015 shall then remain protected until 2030, but not for those made after the $1^{\text {st }}$ of July 2015.

Nonetheless, even without bilateral agreement, the Indonesian Law No 25 of 2007 on Investment still offers some modes of protection for the current and future foreign investments. It is a double-coverage piece of legislation that regulates both domestic investments and foreign investments. ${ }^{57}$ Although the two different origins of investments are dealt separately, 58 the Law has indicated a true effort on legal transparency and attempt on keeping up with the internationally established standard of foreign investments protection. Amongst the general standard of treatments established in the investment treaty regime, the Law explicitly governs the most favoured nations principle, while remains silent on the

\footnotetext{
${ }^{54}$ For instance, see Australia-Indonesia BIT 1992 Art XV (1)

55 Netherlands-Indonesia BIT 1994 Art 15 (1)

56 Ibid Art 15 (2)

57 Undang-Undang No 25 Tabun 2007 tentang Penanaman Modal [Law No 25 of 2007 on Investment] (Indonesia) Art 1 [author's trans] ('Indonesian Investment Law 2007')

${ }^{58}$ For instance, see art 5 on the Forms of Business Entity under the Indonesian Investment Law 2007: domestic investments may take the form of both legal or non-legal business entities or partnership; while foreign investments are obliged to be in the form limited liability company domiciled in the territory of Indonesia.
} 
national treatment principle. ${ }^{59}$ But the answer to that silence might be distilled from its other provisions: Indonesia emphasises on the promotion and advancement of Micro, Small and Medium Enterprises (MSMEs) ${ }^{60}$ and an arrangement of reserved Special Economic Zones in strategic areas for the development of national economy. ${ }^{61}$ Rest assured, the dispute settlement mechanism under the Law lingers on the first stage of amicable settlement ${ }^{62}$ followed by direct right to investment arbitration by the investors by acquire consent of the Indonesian Government. ${ }^{63}$ Additionally, the Law guarantees more specific standard of treatments: non-expropriation or nationalisation, transfer of assets and currency exchange. ${ }^{64}$

The loopholes in the Law perhaps cause uneasiness for foreign investors however, BITs are not always the oasis in the heat of international investment, they simply offer legal umbrella for the protection of strangers in strange lands. Despite BITs being state-to-state commitment, the Indonesian Government still have enter into investment contracts with foreign investors themselves, hence creating the state-to-investor legal obligations (government being the subject of contract law). In this sense, the government and the foreign investor can extend the contract even when the covering BIT has been terminated or they may negotiate a new one based on the existing international investment principles. Investment contracts has its own perks, it is a more specific firsthand commitment that binds the host government and the investors, since it applies as the law for both parties.

For instance, mining and upstream oil and gas are two of the most treasured foreign investment sectors Indonesia. Chevron Pacific Indonesia, ExxonMobil Cepu Limited and China National Oil Offshore Corporation (CNOOC) as of 2018, are the top three oil and gas players. ${ }^{65}$ They operate based on the Production

${ }^{59}$ Indonesian Investment Law 2007 Art 6 (1)

60 Ibid Art 13

${ }^{61}$ Ibid Art 31

62 Ibid Art 32 (1)

63 Ibid Art 32 (4)

${ }^{64}$ Ibid Art 6

${ }^{65}$ Indonesia Investments, "What Are the Biggest Oil and Gas Companies in Indonesia?", IndonesiaInvestments, in https://www.indonesia-investments.com/news/todays-headlines/what-are-the-biggest-oil-gascompanies-in-indonesia/item9000?, accessed in 29 December 2021 
Sharing Contract (PSC) that has been around since the 1960's. ${ }^{66}$ As for mining, PT Freeport Indonesia has been investing in the country since 1967 based on a contract that endured until its first prolongation in 1991, then its second prolongation that dues in 2021. Despite the perpetual economic and social controversies since day one of the contract, it proofs how effective foreign investments operate under contracts.

Nevertheless, it is reasonable for the international community to demand a formal government-to-government commitment in the absence of BITs. In this case, Indonesia's involvement in Regional Trade Agreements (RTAs) with an elaborate investment chapter would be the finest alternative as approved by Indonesian Investment Law of 2007.67

\section{An Alternate Road for Both the Present and the Future: Investment Chapter in RTAs}

RTAs is described as trade agreements between two or more countries which, regardless the word "regional" on its name, may or may not be between those of the same region. ${ }^{68}$ RTAs in the world are broadly and primarily regulated under the WTO system. ${ }^{69}$ Thus from the helicopter view, it seems as if RTAs are merely an integral part of the international trade regime. However upon closer look, RTAs actually lie on the intersection between the two regimes.

The Association of South East Asian Nations (ASEAN) is one of the world's largest and considerably most successful RTAs ${ }^{70}$ by knitting Indonesia, Malaysia, Singapore, Philippines, Thailand, Brunei Darussalam, Viet Nam, Myanmar and Laos - with vast gap of economic development - into single market as in ASEAN Economic Community (AEC) and ASEAN Free Trade Area (AFTA). Despite being an RTA on its own, ASEAN enters into at least six external sub-RTAs ${ }^{71}$ known as

${ }^{66}$ For instance, see Undang-Undang No 22 Tabun 2001 tentang Minyak dan Gas Bumi [Law No 22 of 2001 on Oil and Gas] (Indonesia) [author's trans]

${ }^{67}$ Indonesian Investment Law 2007 Art 6 and its explanatory note

68 Rafael Leal-Arcas, "Proliferation of Regional Trade Agreements: Complementing or Supplanting Multilateralism?”, Chicago Journal of International Law, Vol. 11, No. 2, 2011, p. 600

69 Transparency Mechanism for Regional Trade Agreement, WTO Doc WT/L/671, 18 December 2006 (Decision of 14 December 2006) paras 1-4

70 Jamil Maidan Flores, Jun Abad, “ASEAN At 30”, Association of South East Asian Nations (ASEAN), in http://asean.org/?static post=the-founding-of-asean, accessed in 29 December 2021

${ }^{71}$ World Trade Organisation, List of All RTAs, Including Accessions to RTAs (11 September 2018) World Trade Organisation (WTO), in https://rtais.wto.org/UI/PublicAllRTAList.aspx, accessed in 5 November 2018 
the ASEAN Pluses; ${ }^{72}$ the Regional Comprehensive Economic Partnership (RCEP) with Australia, New Zealand, China, India, Japan and South Korea which is in an ongoing negotiation; ${ }^{73}$ the Asia-Pacific Economic Cooperation $(\mathrm{APEC})^{74}$ which some of its member states are in the Comprehensive and Progressive Agreement of Trans-Pacific Partnership (TPP); ${ }^{75}$ as well as being equipped with its own Comprehensive Investment Agreement (ACIA). Some of ASEAN individual countries also have their separate RTAs. ${ }^{76}$ It proves that RTAs have pure bilateral approach, but unlike the simplicity of BITs, depth and comprehensiveness are their nature both in its entirety or its specific investment chapter. ${ }^{77}$

Indonesia has a couple RTAs on its own, such as the one with Japan ${ }^{78}$ and Australia. ${ }^{79}$ Regardless, to invest in Indonesia, investors from both ASEAN countries and non-ASEAN countries can still pursue the protection of their investments from the provisions under the investment chapter in the ASEANbased RTAs that bind Indonesia.

Investment chapter in ASEAN Plus Two agreement with Australia and New Zealand (AANZFTA) is picked up to measure whether investment chapter in RTA provides the same degree of protection as BITs. Bilateral investment is regulated under Chapter 11 of the AANZFTA. Investment chapter in AANZFTA strictly

${ }^{72}$ Currently comprises of ASEAN+1, ASEAN+2, ASEAN+3 and the latest ASEAN+6 (RCEP). For instance, ASEAN+3 consisted of ASEAN countries, People's Republic of China, Japan and Korea.

73 Shujiro Hirata, "An ASEAN+6 Economic Partnership: Significance and Tasks", Asia Research Report, Japan Centre for Economic Research, 2007, p. 2

${ }^{74}$ During its negotiation process, by the rejection of Indonesia, Malaysia and Thailand, APEC remains as more of a laid-back consultative and negotiation forum rather than a formal institution. Even so, its commitment lies firmly on the free flow of trades and investments with the Individual Action Plan and the Early Voluntary Sectoral Liberalisation as part of its fundamental system. APEC membership is currently composed of the ASEAN Countries, Australia, New Zealand, United States, Canada, Mexico, Chile, Peru, Russia, China, Japan, Chinese Taipei, Republic of Korea, Hong Kong and Papua New Guinea. Asia-Pacific Economic Cooperation, "About APEC", Asia-Pacific Economic Cooperation (APEC), in https://www.apec.org/AboutUs/About-APEC, accessed in 29 December 2021

${ }^{75}$ Interestingly, TPP is born out of the failure to turn APEC into a formal institution. Thus, ASEAN countries have no unanimous voice for participating in TPP. Only Malaysia, Singapore, Viet Nam and Philippines consent to engage in TPP based on varied considerations based on each of the country's economical needs and development. Thailand has not expressed its consent nor rejection. Indonesia rejects blatantly. Ganjar Nugroho, “An Overview of ASEAN States' RTA Strategy”, Waseda Universtiy Japan, in https://www.waseda.jp/inst/oris/assets/uploads/2015/10/i2-3.pdf accessed in 29 December 2021

${ }^{76}$ For instance, see Agreement Between Japan and the Republic of Indonesia for an Economic Partnership, JapanIndonesia, signed 20 August 2007, WT/REG241 (entered into force 1 July 2008)

77 Ibid

${ }^{78}$ Ibid

79 Department of Foreign Affairs and Trade, "Indonesia-Australia Comprehensive Economic Partnership Agreement Outcomes", Australian Government, in https://dfat.gov.au/trade/agreements/not-yet-inforce/iacepa/Pages/ia-cepa-key-outcomes-for-australia.aspx, accessed in 29 December 2021 
excludes government procurements, government service supplies for public purposes, trade in services and movement of natural persons; ${ }^{80}$ while consistently keeping an inclusive and open-ended definition of investments as established by the treaty regime. ${ }^{81}$ It guarantees the general standard of treatments: national treatment, ${ }^{82}$ fair and equitable treatment; non-denial of justice ${ }^{83}$ and full protection and security. ${ }^{84}$ Its specific standard of treatments covers compensation for losses, 85 transfers, ${ }^{86}$ and expropriation. ${ }^{87}$ The investment chapter denies the aforementioned benefits to apply to the subsidiary of non-party that has no substantive business operation base in the host state territory. ${ }^{88}$ An interesting innovation of the AANZFTA is that it moves forward to the possibility of regulating investment in services that are not included in commercial presence mode under international trade law, as an attempt to align with the latter regime. ${ }^{89}$

Aside of that general overview, AANZFTA's approach on dispute settlement mechanism and expropriation provisions - two of the most focal points in international investment law - are worthy of praises for its specificity and clarity. Essentially, it converts all the principal elements of dispute settlement in common BITs while elaborating them into a more forthright and particularised version: it clarifies the scope of dispute; 90 when can an investor file the dispute; 91 legal and factual grounds to bring the dispute into settlement forum (amicable or arbitration alike); ${ }^{92}$ rules and procedures of the forum (ICSID Convention, ICSID Arbitration Rules, ICSID Additional Facility for non-ICSID members and UNCITRAL Arbitration Rules remain the favourite); ${ }^{93}$ nature and characteristics of the Award; in what conditions the investors may demand the enforcement of

80 Agreement Establishing the ASEAN-Australia- New Zealand Free Trade Area, ASEAN-Australia-New Zealand, signed 27 February 2009, WT/REG284/N/1 (entered into force 1 January 2010) ch 11 art 1 (2) ('AANZFTA)

${ }^{81}$ Ibid Art 2

82 Ibid Art 4

${ }^{83}$ Ibid Art 6 (1)

${ }^{84}$ Ibid

85 Ibid Art 7

86 Ibid Art 8

${ }^{87}$ Ibid Art 9

${ }^{88}$ Ibid Art 11 (1) (a)

${ }^{89}$ Ibid Art 16 (1)

${ }^{90}$ Ibid Art 18

${ }^{91}$ Ibid Art 22 (1)

${ }^{92}$ Ibid Art 20 (a)

93 Ibid Art 21 (1) 
the Award; ${ }^{94}$ the host state's obligation upon the investors' right to seek interim measures for the protection of their rights and interests; 95 settlement for disputes arise from taxation measures; ${ }^{96}$ and most interestingly, to determine whether such measures amount to indirect expropriation or nationalisation is by consultation between parties, followed by the conciliation or arbitration. ${ }^{97}$

As for expropriation or nationalisation, it comes with a special annex that differentiates direct ("formal transfer of title or outright seizures") 98 and indirect ("any governmental measures that has the identical effect to expropriation or nationalisation, even without formal transfer of title or outright seizures") $)^{99}$ expropriation. Indirect expropriation is defined casuistry based on the major economic impact of the measures, its character, the government's objective or intent, and the proportionality of the measures with public purposes such as public health, safety and environmental protection. ${ }^{100}$

It all sounds like a sufficiently comprehensive investment chapter, which reaches deeper and wider than the treaty regime. Yet one may still argue on the apparent missing of the most favoured nations principle. In BITs regime, most favoured nations principle is somewhat destructive: it simply forces the states to rewrite their treaty bargain, on the stacks of other treaties upon treaties in the whole BITs network; it is still in a heated debate on whether the principle extends to dispute settlement ${ }^{101}$ or not, ${ }^{102}$ while in practise, procedural difference is what the lawyers are often dwelling with. Most favourite nations principle has become a favourite claim, alongside the fair and equitable treatment and national treatment claims. Except in formulating the claim, the comparator to establish the "like treatments" must not be distilled from those of the regional agreements, free trade areas, custom unions, or common market. That is precisely why for the

94 Ibid Art 28

95 Ibid Art 22 (2)

96 Ibid Art 25

${ }^{97}$ Ibid

98 Ibid annex for Expropriation and Compensation para 2 (a)

${ }^{99}$ Ibid annex for Expropriation and Compensation para 2 (b)

100 Ibid annex for Expropriation and Compensation para 3

${ }^{101}$ Emilio Agustin Maffezini v The Kingdom of Spain (Award) (ICSID Arbitral Tribunal) Case No ARB/97/7 (13 November 2000)

102 Plama Consortium Ltd v Republic of Bulgaria (Award) (ICSID Arbitral Tribunal) Case No ARB/03/24 (27 August 2008) 
specific field of most favoured nations, RTAs prevail over BITs. By their very nature, RTAs amount to a justifiable defiance against the principle. In the end, however, ASEAN/Indonesia RTAs are merely an alternative as they only benefit the member states. As for investments flowing from the non-members, Indonesia's new model BIT awaits.

\section{The Future and the Way Forward: Indonesia's New Model BIT}

Indonesia has had its own Model BIT ${ }^{103}$ but disappointingly, it is no different than the "old generation" of template BITs. ${ }^{104}$ It is still a simple and short document with open-ended language that would not serve the country's economic interests more than what the previous BITs have. To actually live up to the economic nationalism, Indonesia needs to re-formulate its Model BIT. If done correctly, not only it would benefit the country, but it would also provide the higher certainty for the investors. In formulating the new Model BIT, these following issues must be addressed: First and foremost, the definition and scope of investments must be crystal clear. The long reign of open-ended and inclusive BITs language must come to an end. For example, in its new Model BITs, India has narrowed the definition of investments to "enterprise-based" instead of "asset-based". 105 Limiting the coverage of investments would then classify the investment assets, thus regulating what falls under the protection. Further clarification must also be shed on other types aside of FDI, such as portfolio investments, securities or other capital market instruments, as well as Intellectual Property Rights (IPR) matters.

Second, Fair and equitable treatment, if not exclusively defined, will continue to become an all-in provision on which investors are popularly known to sue the host state - and the former win oftentimes. In order to maintain the fair protection of investments, legitimate expectation, due process of law, transparency and good faith may be added alongside the denial of justice (as found in AANZFTA) in the

${ }^{103}$ United Nations Conference on Trade and Development (UNCTAD), "Indonesia Investment Related Instruments (IRIs)" Investment Policy Hub, in http://investmentpolicyhub.unctad.org/IIA/CountryIris/97, accessed in 5 November 2018

104 Anthony Crockett, "Indonesia's Bilateral Investment Treaties: Seeking an Equitable Climate for Investment?”, ICSID Review Vol. 30, No. 2, 2015

105 David Price, “Indonesia's Bold Strategy on Bilateral Investment Treaties”, Asian Journal of International Law, Vol. 7, No. 8, 2007 
fair and equitable treatment. ${ }^{106}$ Third, redefining the scope of direct and indirect expropriation or nationalisation. Indonesia as a state must maintain its sovereign power to regulate its law on public purposes such as public morality, public order, social welfare, health, environmental protection and sustainable development. Investors should not easily claim a public measure as indirect expropriation. AANZFTA and a plethora of RTAs (such as the Comprehensive Economic and Trade Agreement - CETA - between Canada and the European Union) ${ }^{107}$ have introduced this exception. ${ }^{108}$ Fourth, provision to prevent "treaty-shopping" in which a non-party third state can enjoy the benefits extended from the BIT protection through the subsidiary company owned by juridical person of the party that is controlled by the third state. ${ }^{109}$ Fifth, despite the current pessimism, provision on transfer of knowledge and technology to the locals is needed direly. It is a rare gem that can hardly be found in present FDIs indeed but even the world's first ever BIT had it despite its brief, simple and intentionally open-ended language, ${ }^{110}$ hence it should not be too impossible to re-introduce, Last but certainly not least, incorporating exhaustion of local remedies into the dispute settlement provision, as what has been done by India in its Model BIT, ${ }^{111}$ plus written consent of both parties before the dispute escalates into an ISDS forum. ${ }^{112}$

\section{Conclusion}

The paper opens up by bringing forward two seemingly simple yet intricate issues in regards to the present and the future of foreign investment in Indonesia which, through the lengthy discussion above, these two conclusions are drawn:

106 OECD, "Fair and Equitable Treatment Standard in International Investment Law", Working Paper No 2004/03, OECD Working Paper on International Investment, 2004, p. 28-39

107 Joint Interpretative Instrument on the Comprehensive Economic and Trade Agreement (CETA) between Canada and European Union and Its Member States, Canada-EU, 27 October 2016, 13541/16 WTO 300 Services 28 FDI 23 CDN 24

108 AANZFT $A$ annex for Expropriation and Compensation para 3

${ }^{109}$ Roeline Knotterus, Roos van Oss, "The Netherlands: A Gateway to 'Treaty Shopping' for Investment Protection", International Institute for Sustainable Development, in https://www.iisd.org/itn/2012/01/12/, accessed in 5 November 2018

110 Germany-Pakistan BIT, Art. 10

111 Department of Economic Affairs, "Model Text for the Indian Bilateral Investment Treaty", Government of India, in https://www.mygov.in/sites/default/files/master image/Model $\% 20$ Text $\% 20$ for $\% 20$ the $\% 20$ Indian $\% 20$ Bilateral $\% 20$ Investment $\% 20$ Treaty.pdf, accessed in 29 December 2021

112 Sefriani, "The New Model of Bilateral Investment Treaty (BIT) for Indonesia”, Journal of Legal, Ethical and Regulatory, Vol. 21, Issues 1, 2018, p. 11 
1. Earnest realisation of the true value of economic nationalism has determined Indonesia to re-evaluate its BITs, by terminating them. BITs do signal Indonesia's credible commitment to protect foreign investment, but terminating them does not indicate otherwise. Foreign capitals have unceasingly flown in and out of Indonesia which suffices to validate its commitment. The end of the BITs regime does not mean the end international investments in Indonesia, the investors' rights and interests are still embodied in the sunset clause of the terminated BITs and the investor-state contracts; alternatively, other legal vehicles are present which are the country's national laws and investment chapter under a good number RTAs that provide equally reliable degree of protection. The vanishing of BITs does not lead to the vanishing of the foreign investment protection.

2. As for nurturing its of economic development while staying true to its credible commitment, Indonesia needs to re-formulation of a new Model BIT that would truly serve its interests and upholds its values.

\section{Bibliography}

\section{Books}

Dolzer, Rudolf and Christophe Schreuer, Principles of International Investment Law, Oxford University Press, Oxford, 2012.

Newcombe, Andrew and Lluis Paradell, Law and Practise of Investment Treaties, Kluwer, 2009.

Schreuer, Christhophe and Matthew Weiniger, "A Doctrine of Precedent?", in Peter Muchlinski et al (eds), The Oxford Handbook of International Investment Law, Law-book, 2008.

Shea, DR, The Calvo Clause, University of Minnesota Press, Minnesota, 1955.

\section{Journal}

Guzman, Andrew, "Why LDCs Sign Treaties that Hurt Them; Explaining the

Popularity of Bilateral Investment Treaties", Virginia Journal of International Law, Vol. 38, 2006.

Crockett, Anthony, “Indonesia's Bilateral Investment Treaties: Seeking an Equitable Climate for Investment?", ICSID Review Vol. 30, No. 2, 2015.

Dahlman, Christian, "The Function of Opinio Juris in Customary International Law", Nordic Journal of International Law, Vol. 81, Issue 3, 2012. 
Price, David, "Indonesia's Bold Strategy on Bilateral Investment Treaties", Asian Journal of International Law, Vol. 7, No. 8, 2007.

Root, Elihu, "The Basis of Protection to Citizen's Residing Abroad", American Journal of International Law, Vol. 4, Issue 3, 1910.

Kelsen, Hans, “The Principle of Sovereign Equality of States as A Basis of International Organisation", Yale Law Journal, Vol. 53, 1944.

Shihata, Ibrahim, “Towards a Greater Depoliticization of Investment Disputes: The Role of ICSID and MIGA", ICSID Review, Vol. 1, No. 1, 1986.

Salacuse, Jeswald W, "The Emerging Global Regime for Investment", Harvard International Law Journal, Vol. 51, No. 2, 2010.

Poulsen, Lauge, "Bounded Rationality and the Diffusion of Modern Investment Treaties", International Studies Quarterly, Vol. 58, Issue 1, 2014.

Poulsen, Lauge and Emma Asbett, "When the Claim Hits: Bilateral Investment Treaties and Bounded National Learning", World Politics Vol. 65, No. 2, 2003.

Ranjan, Prabash, "Indian Investment Treaty Program in Light of Global Experience", Economic and Political Weekly, Vol. 39, No. 45, 2010.

Leal-Arcas, Rafael, "Proliferation of Regional Trade Agreements: Complementing or Supplanting Multilateralism?", Chicago Journal of International Law, Vol. 11, No. 2, 2011.

Sefriani, "The New Model of Bilateral Investment Treaty (BIT) for Indonesia", Journal of Legal, Ethical and Regulatory, Vol. 21, Issues 1, 2018.

United States Secretary of State, "Mexico-United States: Expropriation by Mexico of Agrarian Properties Owned by American Citizens", American Journal of International Law, Vol. 33, 1983.

Elkins, Zachary, Andrew T Guzman and Beth A. Simmons, "Competing for Capital: The Diffusion of Bilateral Investment Treaties, 1960-2000", International Organization, Vol. 60, No. 4, 2006.

\section{Articles, Reports, and Other Documents}

James H Mathis, "Regional Trade Agreements in the GATT/WTO: Article XXIV and the Internal Trade Requirement", TMC Asser Press, 2002.

Kevin Muhammad Haikal, “Foreign Investment Protection Post-Indonesia's Bilateral Investment Treaties Regime", Thesis, Tilburg University, 2017.

Mark Beeson and Andrew Rosser, "The East Asian Economic Crisis: A Brief Overview of the Facts, the Issues and the Future" Working Paper No 86, Asia Research Centre, June 1998.

OECD, "Fair and Equitable Treatment Standard in International Investment Law", Working Paper No 2004/03, OECD Working Paper on International Investment, 2004. 
Shujiro Hirata, “An ASEAN+6 Economic Partnership: Significance and Tasks”, Asia Research Report, Japan Centre for Economic Research, 2007.

Stephen L Magiera, “International Investment Agreements and Investor-State Disputes", Discussion Paper No 30, ERIA, January 2017.

\section{Indonesian Legislation}

Undang-Undang No 25 Tahun 2007 tentang Penanaman Modal [Law No 25 of 2007 on Investment] (Indonesia) art 1 [author's trans]

\section{Treaties}

Agreement Between the Government of Australia and the Government of the Republic of Indonesia Concerning the Promotion and Protection of Investments, AustraliaIndonesia, signed 17 November 1992, 1770 UNTS 301 (entered into force 29 July 1993).

Agreement Between the Government of the Kingdom of the Netherlands and the Government of the Republic of Indonesia on Promotion and Protection of Investments, Netherlands-Indonesia, signed 4 June 1994, 2240 UNTS 323 (entered into force 1 July 1995).

Agreement Between the Government of Malaysia and the Government of the Republic of Indonesia for the Promotion and Protection of Investments, MalaysiaIndonesia, signed 22 January 1994, (entered into force 2 October 1999).

Agreement Between the Government of the Republic of Indonesia and the Government of the Kingdom of Thailand for the Promotion and Protection of Investments, Indonesia-Thailand, signed 17 February 1998, 1489 UNTS 3 (entered into force 5 November 1998).

Agreement Between the Government of the Republic of Singapore and the Government of the Republic of Indonesia on the Promotion and Protection of Investments, Singapore-Indonesia, signed 16 February 2005 (entered into force 21 June 2006).

Agreement Between the Government of the United Kingdom of Great Britain and Northern Ireland and the Government of the Republic of Indonesia for the Promotion and Protection of Investments, United Kingdom-Indonesia, signed 27 April 1976, 575 UNTS 159 (entered into force 24 March 1977).

Agreement Between Japan and the Republic of Indonesia for an Economic Partnership, Japan-Indonesia, signed 20 August 2007, WT/REG241 (entered into force 1 July 2008).

Agreement Establishing the ASEAN-Australia- New Zealand Free Trade Area, ASEANAustralia-New Zealand, signed 27 February 2009, WT/REG284/N/1 (entered into force 1 January 2010).

Agreement on Economic Cooperation, The Netherlands-Indonesia, signed 7 July 1968, 1155 UNTS 243 (entered into force 17 July 1971) 
Convention on the Settlement of Investment Disputes Between States and Nationals of Other States, opened for signature 18 March 1965, 575 UNTS 159 (entered into force 14 October 1966).

Marrakesh Agreement Establishing the World Trade Organization, opened for signature 15 April 1994, 1867 UNTS 3 (entered into force 1 January 1995) annex 2 ('Understanding on Rules and Procedures Governing the Settlement of Disputes').

Treaty for the Promotion and Protection of Investments (with Protocol and Exchange of Notes), Germany-Pakistan, signed 25 November 1959, 457 UNTS 24 (entered into force 28 November 1962).

\section{Decisions}

ADC Affiliate Ltd and ADC \& ADMC Management Ltd $v$ Republic of Hungary (Award) (ICSID Arbitral Tribunal) Case No ARB/03/16 (2 October 2006).

Churchill Mining PLC and Planet Mining Pty Ltd $v$ Republic of Indonesia (Jurisdiction) (ICSID Arbitral Tribunal) Cases No. ARB/12/14 and ARB/12/40 (24 February 2014).

Emilio Agustín Maffezini v The Kingdom of Spain (Award) (ICSID Arbitral Tribunal) Case No ARB/97/7 (13 November 2000).

Nusa Tenggara Partnership BV and PT Newmont Nusa Tenggara $v$ Republic of Indonesia (Discontinued) (ICSID Arbitral Tribunal) Case No ARB/14/15 (August 2014).

Oleovest Pte Ltd $v$ Republic of Indonesia (Pending Jurisdiction) (ICSID Arbitral Tribunal) Case No ARB/16/26 (2016).

Plama Consortium Ltd $v$ Republic of Bulgaria (Award) (ICSID Arbitral Tribunal) Case No ARB/03/24 (27 August 2008).

Permanent Sovereignty Over Natural Resources, GA Res. 1803 (XVII), UN GAOR, 28 ${ }^{\text {th }}$ sess, Supp No 17, UN Doc. A/5217 (14 December 1962).

Siemes AG $v$ The Argentine Republic (Jurisdiction) (ICSID Arbitral Tribunal) Case No. ARB/02/8 (3 Agustus 2004).

Transparency Mechanism for Regional Trade Agreement, WTO Doc WT/L/671, 18 December 2006 (Decision of 14 December 2006).

\section{Others}

Joint Interpretative Instrument on the Comprehensive Economic and Trade Agreement (CETA) between Canada and European Union and Its Member States, Canada-EU, 27 October 2016, 13541/16 WTO 300 Services 28 FDI 23 CDN 24.

UNCTC, BIlatral Investment Treaties, UN Doc No ST/CTC/65 (1988). 


\section{Internet}

Asia-Pacific Economic Cooperation, "About APEC", Asia-Pacific Economic Cooperation (APEC) < https://www.apec.org/About-Us/About-APEC > (last accessed 29 December 2021)

Bagus BT Saragih, "SBY Frets Over International Arbitration", The Jakarta Post < http://www.thejakartapost.com/news/2012/06/29/sby-frets-over-int-larbitration.html $>$ (last accessed 29 December 2021)

Department of Economic Affairs, "Model Text for the Indian Bilateral Investment Treaty", Government of India < https:// www.mygov.in/sites/default/files/master_image/Model\%20Te xt\%20for\%20the\%20Indian\%20Bilateral\%20Investment\%20Treaty.pdf $>$ (last accessed 29 December 2021)

Department of Foreign Affairs and Trade, "Indonesia-Australia Comprehensive Economic Partnership Agreement Outcomes", Australian Government < https://dfat.gov.au/trade/agreements/not-yet-inforce/iacepa/Pages/ia-cepa-key-outcomes-for-australia.aspx $>$ (last accessed 29 December 2021)

Government of Indonesia, "Letter of Intent", International Monetary Fund < https://www.imf.org/external/np/loi/1113a98.htm $>$ (last accessed 29 December 2021)

Indonesia Investments, "What Are the Biggest Oil and Gas Companies in Indonesia?", Indonesia-Investments < https://www.indonesiainvestments.com/news/todays-headlines/what-are-the-biggest-oil-gascompanies-in-indonesia/item9000? > (last accessed 29 December 2021)

Jamil Maidan Flores and Jun Abad, “ASEAN At 30”, Association of South East Asian Nations (ASEAN) < http://asean.org/?static post=the-foundingof-asean $>$ (last accessed 29 December 2021)

John Lumbantobing, "Renegotiating the Bite of Our BITs", Jakarta Post < http://www.thejakartapost.com/news/2015/05/18/renegotiating-biteour-bits.html $>$ (last accessed 29 December 2021)

Kingdom of the Netherlands, "Termination Bilateral Investment Treaty", Embassy of the Netherlands < http://indonesia.nlembassy.org/organization/departments/economicaffairs/termination- bilateral-investment-treaty.html $>$ (last accessed 5 November 2018)

Leon E Trakman and Kunal Sharma, "Why is Indonesia Terminating Its Bilateral Investment Treaties?", Kluwer Arbitration < http://arbitrationblog.kluwerarbitration.com/2014/08/21/indonesiastermination-of-the-netherlands-indonesia-bit-broader-implications-in-theasia-pacific/ > (last accessed 29 December 2021) 
Minister for Foregin Affairs Republic of Indonesia, "Annual Press Statement (2015)", The Ministry of Foreign Affairs Republic of Indonesia < https://www.kemlu.go.id/Documents/PPTM\%202015/PPTM\%202015\% 20ENG\%20FINAL\%20PDF.pdf > (last accessed 5 November 2018)

Norton Rose Fulbright, "Indonesia Signals Intention to Terminate More than 60 Bilateral Investment Treaties", Norton Rose Fulbright < http:/ / www.nortonrosefulbright.com/knowledge/publications/116101/ indonesia-signals-intention-to-terminate-more-than-60-bilateral$\underline{\text { investment-treaties }}>$ (last accessed 5 November 2018)

Ganjar Nugroho, "An Overview of ASEAN States' RTA Strategy", Waseda Universtiy Japan < https://www.waseda.jp/inst/oris/assets/uploads/2015/10/i2-3.pdf > (last accessed 29 December 2021)

Roeline Knotterus and van Oss, Roos, "The Netherlands: A Gateway to 'Treaty Shopping' for Investment Protection", International Institute for Sustainable Development < https://www.iisd.org/itn/2012/01/12/ > (last accessed 5 November 2018)

United Nations Conference on Trade and Development (UNCTAD), "Indonesia Bilateral Investment Treaties", Investment Policy Hub < http://investmentpolicyhub.unctad.org/IIA/CountryBits/97 > (last accessed 5 November 2018)

United Nations Conference on Trade and Development (UNCTAD), "Indonesia Investment Related Instruments (IRIs)", Investment Policy Hub < http://investmentpolicyhub.unctad.org/IIA/CountryIris/97 > (last accessed 5 November 2018)

United Nations Conference on Trade and Development (UNCTAD), “IndonesiaNetherlands BIT 1994", Investment Policy Hub < http://investmentpolicyhub.unctad.org/IIA/mostRecent/treaty/1988 > (last accessed 5 November 2018)

World Trade Organisation, "List of All RTAs, Including Accessions to RTAs", World Trade Organisation (WTO) < https://rtais.wto.org/UI/PublicAllRTAList.aspx $>$ (last accessed 5 November 2018) 